\begin{tabular}{cc|c}
\hline Tar. Bil. Der. & Journal of Agricultural Sciences \\
& $\begin{array}{c}\text { Dergi web sayfası: } \\
\text { www.agri.ankara.edu.tr/dergi }\end{array}$ & Journal homepage: \\
& www.agri.ankara.edu.tr/journal
\end{tabular}

\title{
Comparison of Hens Reared in Free-Range and Deep-Litter Systems in Terms of Certain Production Characteristics
}

\author{
İsmail TÜRKER ${ }^{\mathrm{a}}$, Sezai ALKAN ${ }^{\mathrm{b}}$ \\ ${ }^{a}$ Bozok University, Faculty of Agriculture, Department of Animal Science, Yozgat, TURKEY \\ ${ }^{\boldsymbol{b}}$ Ordu University, Faculty of Agriculture, Department of Animal Science, Ordu, TURKEY
}

\section{ARTICLE INFO}

Research Article DOI: 10.15832/ankutbd.446434

Corresponding Author: Ismail TÜRKER, E-mail: iturker37@hotmail.com, Tel: +90 (354) 2421028

Received: 27 December 2016, Received in Revised Form: 30 January 2017, Accepted: 30 January 2017

\begin{abstract}
The study was carried out compare the hens reared in free range system and deep-litter system in terms of certain production characteristics. A total of 300 Lohmann Brown hens, with 150 hens in each of the groups were used in the study. In the free range system, $4 \mathrm{~m}^{2}$ grazing ground was allocated for each hen. The hens were taken into research henhouse at 16 weeks of age and production characteristics were determined up to 52 weeks of age. It was determined that out of the characteristics focused in the study, there is no significant difference between the groups in terms of viability, $50 \%$ production age, egg weight, hen-day egg production, feed efficiency, feed consumption and body weight at 18 week of age, whereas there is a significant difference in terms of final body weight. In the study, it was concluded that hens in the deep-litter system gained more body weight compared to those in the free-range system but the other characteristics were not affected by the husbandry systems.

Keywords: Free range system; Deep-litter system; Egg production age; Feed efficiency; Body weight
\end{abstract}

\section{Serbest ve Altlıklı Yer Sisteminde Yetiştirilen Tavukların Bazı Verim Özelliklerinin Karşılaştırılması}

\section{ESER BILGİí}

Araştırma Makalesi

Sorumlu Yazar: İsmail TÜRKER, E-posta:iturker37@hotmail.com, Tel: +90 (354) 2421028

Geliş Tarihi: 27 Aralık 2016, Düzeltmelerin Gelişi: 30 Ocak 2017, Kabul: 30 Ocak 2017

\section{ÖZET}

Araştırma serbest sistem ve altlıklı yer sisteminde yetiştirilen tavukların bazı verim özellikleri bakımından karşılaştırılması amaciyla yürütülmüştür. Her yetiştirme sisteminde 150 adet olmak üzere toplam 300 adet Lohmann Brown tavuk kullanılmıştır. Serbest sistemde tavuk başına $4 \mathrm{~m}^{2}$ otlatma alanı ayrılmıştır. Tavuklar 16 haftalık yaşta araştırma kümesine alınmış ve 52 haftalık yaşa kadar verim özellikleri belirlenmiştir. Araştırmada üzerinde durulan özelliklerden yaşama gücü, \% 50 verim yaşı, yumurta ağırlığı, tavuk-gün yumurta verimi, yem tüketimi, yemden yararlanma oranı ve dönem başı canlı ağırlığı bakımından gruplar arasında farklılık bulunmadığı, dönem sonu canlı ağırlığı bakımından ise önemli farklılık olduğu belirlenmiștir. Araştırmada altlıklı yer sistemindeki tavukların serbest sisteme göre daha fazla canlı ağırlık kazandıkları, ancak diğer özelliklerin yetiştirme sistemlerinden etkilenmediği sonucuna varılmıştır.

Anahtar Kelimeler: Tavuk; Serbest sistem; Altlıklı sistem; Yumurta verimi; Yem tüketimi 


\section{Introduction}

Most consumers prefer eggs produced through alternative production systems that apply food safety regulations since animal rights started to be considered important in egg production systems (Anderson 2009). There are various alternative production systems available such as free range, organic, enriched cage, aviary and deep-litter systems.

Hen strains and husbandry systems are effecting the egg quality traits (Doley et al 2010; Angelovičová et al 2014; Nistor et al 2014; Yang et al 2014; Hanusová et al 2015; Nistor et al 2015).

It has been determined that the strains used in production shown different reaction to husbandry systems (Leyendecker et al 2001). It has been reported by Doley et al (2010) that the body weight of hens reared in deep-litter systems are higher than those reared in the free range and semi-intensive systems. Hill (1986) stated that the egg eating habit is more common in deep-litter systems compared to aviary, strawyard, perchery and free range systems.

It is observed that producing eggs in the cage system is more hygienic and economic compared to the other systems, however, it creates the disadvantage of limited movements for hens. It has been reported that the eggs produced through cage system have darker yellow yolks and they are heavier in weight and the hens have lower mortality, feed consumption, body weight, dirty and cracked egg rate (Wegner 1982). Sekeroglu et al (2010) emphasized that husbandry systems have to be studied in detail.

Since egg production is important in alternative production systems in terms of both variation and animal welfare, the effects of these systems on productivity and quality should be investigated in detail. Although various studies on the subject exist, they are not sufficient.

In this research, it was aimed to compare hens reared in deep-litter systems and free range systems in terms of certain productivity traits.

\section{Material and Methods}

A total of 300 Lohmann Brown hens, with 150 hens in each of the groups were used in the study. The study was carried out with a research henhouse in Ordu city located in the Black Sea Coast which has a humid and warmish climate in the summer and temperate and rainy climate in the winter. This research was conducted between July 2015 and July 2016. In the free range system, a green area of 4 $\mathrm{m}^{2}$ was allocated for each hen out of the henhouse. Green area is consist of Trifolium repens, Trifolium pretense, Lolium perenne, Festuca rubra, Urtica dioica, Bellis perennis and Primula spp. Five hens were placed in each meter square in henhouse. The chemical composition of feed materials was given in Table 1. The hens were placed in henhouse at 16 weeks of age. In the study, the lighting period was applied as 13 hours up to $18^{\text {th }}$ week and after the $18^{\text {th }}$ week it was stabilized at 16 hours with 1 hour increment per week increase. The water and feed were provided ad libitum. This study was conducted in accordance with the ethical rules concerning the animal rights in Turkey.

\subsection{Measurements}

\subsubsection{Body weight at 18 week of age}

Body weight of all hens in the research groups were weighted individually at 18 weeks of age using a scale with $0.01 \mathrm{~g}$ sensitivity.

\subsubsection{Egg production age}

Egg production ratio was calculated based on the age (day) of the hens reached 50\% egg production.

\subsubsection{Egg production}

By considering the eggs produced in each replication, hen-day $\%$ was calculated.

\subsubsection{Egg weight}

From periods of 4 weeks, $20 \%$ of the eggs from each reproduction were selected randomly and weighed using a scale with $0.01 \mathrm{~g}$ sensitivity. 
Table 1- Chemical compositions of feed material

\begin{tabular}{|c|c|c|c|c|}
\hline Nutrients & $0-3$ weeks & 4-10 weeks & 11-16 weeks & 17-52 weeks \\
\hline Dry matter, $\min (\%)$ & 88.0 & 88.0 & 88.0 & 88.0 \\
\hline Crude ash, $\max (\%)$ & 8.0 & 8.0 & 8.0 & 8.0 \\
\hline Crude protein, $\min (\%)$ & 19.0 & 18.0 & 16.0 & 17.0 \\
\hline Metabolic energy, $\min \left(\mathrm{kcal} \mathrm{kg}^{-1}\right)$ & 2900 & 2800 & 2700 & 2800 \\
\hline Calcium, min-max (\%) & $1-1.2$ & $1-1.1$ & $0.9-1.0$ & $3.5-4.0$ \\
\hline Available phosphorus, $\min (\%)$ & 0.45 & 0.42 & 0.40 & 0.40 \\
\hline Lysine, $\min (\%)$ & 1.15 & 0.98 & 0.72 & 0.75 \\
\hline Methionin, $\min (\%)$ & 0.55 & 0.47 & 0.35 & 0.47 \\
\hline Methonin+cystein min (\%) & 0.85 & 0.76 & 0.58 & 0.78 \\
\hline Triptophan, $\min (\%)$ & 0.20 & 0.19 & 0.17 & 0.20 \\
\hline $\mathrm{NaCl}, \min -\max (\%)$ & $0.35-0.50$ & $0.35-0.50$ & $0.35-0.50$ & $0.35-0.50$ \\
\hline Crude cellulose, $\max (\%)$ & 4.5 & 5.0 & 6.0 & 6.0 \\
\hline Linoleic acid, $\min (\%)$ & 1.5 & 1.25 & 1.0 & 1.7 \\
\hline A vitamin (IU kg-1) & 13000 & 13000 & 10000 & 12000 \\
\hline $\mathrm{D}_{3}$ vitamin $\left(\mathrm{IU} \mathrm{kg}^{-1}\right)$ & 3000 & 3000 & 2000 & 2500 \\
\hline E vitamin $\left(\mathrm{mg} \mathrm{kg}^{-1}\right)$ & 20.0 & 20.0 & 20.0 & 20.0 \\
\hline $\mathrm{K}_{3} \operatorname{vitamin}\left(\mathrm{mg} \mathrm{kg}^{-1}\right)$ & 2.0 & 2.0 & 2.0 & 2.0 \\
\hline $\mathrm{B}_{2} \operatorname{vitamin}\left(\mathrm{mg} \mathrm{kg}^{-1}\right)$ & 5.0 & 5.0 & 5.0 & 5.0 \\
\hline $\mathrm{B}_{12} \operatorname{vitamin}\left(\mathrm{mg} \mathrm{kg}^{-1}\right)$ & 0.02 & 0.02 & 0.01 & 0.01 \\
\hline $\operatorname{Niacin}\left(\mathrm{mg} \mathrm{kg}^{-1}\right)$ & 60.0 & 60.0 & 30.0 & 25.0 \\
\hline Mangan $\left(\mathrm{mg} \mathrm{kg}^{-1}\right)$ & 100 & 100 & 100 & 60.0 \\
\hline Zinc $\left(\mathrm{mg} \mathrm{kg}^{-1}\right)$ & 70.0 & 70.0 & 70.0 & 40.0 \\
\hline Iron $\left(\mathrm{mg} \mathrm{kg}^{-1}\right)$ & 40.0 & 40.0 & 40.0 & 40.0 \\
\hline Cupper (mg kg-1) & 7.0 & 7.0 & 7.0 & 7.0 \\
\hline Selenium $\left(\mathrm{mg} \mathrm{kg}^{-1}\right)$ & 0.2 & 0.2 & 0.2 & 0.2 \\
\hline Cobalt $\left(\mathrm{mg} \mathrm{kg}^{-1}\right)$ & 0.5 & 0.5 & 0.5 & 0.5 \\
\hline
\end{tabular}

\subsubsection{Feed consumption}

Feed consumption was calculated with Equation 1.

Feed consumption $(\mathrm{g})=($ Given feed $(\mathrm{g})$ - remaining feed $(\mathrm{g})) /($ Number of hens $\mathrm{x}$ day)

\subsubsection{Feed efficiency}

Feed efficiency was calculated with Equation 2.

Feed efficiency $=$ Total given feed $(\mathrm{kg}) /$ Total produced eggs $(\mathrm{kg})$

\subsubsection{Final body weight}

The body weights of all hens in the research groups were weighted individually at 52 weeks of age using a scale with $0.01 \mathrm{~g}$ sensitivity.

\subsubsection{Viability}

Viability was calculated from 18 to 52 weeks considering the dead hens at each replication with Equation 3.

Viability $(\%)=($ Number of dead hens $) /($ Number of remaining hens) x 100

\subsection{Statistical analysis}

For all traits included in the study, the control of normal distribution was done by using KolmogorovSmirnov test. T-test was used in the evaluation of the traits which fulfill the assumptions. For the data expressed as rates and \%, angle transformation was applied. 


\section{Results and Discussion}

As a result of the evaluation of the data obtained in the research, findings regarding the body weight of beginning of period, 50\% egg production age, egg production and egg weight are presented in Table 2. Feed consumption, feed efficiency, viability and final body weight values are presented in Table 3. Out of the traits considered in the study, it was determined that there is no significant difference in terms of body weight at 18 week of age, $50 \%$ egg production age, hen-day egg production, egg weight, feed efficiency and viability between husbandry systems $(\mathrm{P}>0.05)$, whereas there is a significant difference in terms of final body weight $(\mathrm{P}<0.05)$.

Since the hens had been reared in deep-litter system until they were transferred into the research henhouse a difference is not expected in terms of body weight at 18 week of age between husbandry systems. However Malik \& Singh (2010) have reported that there are important differences between husbandry systems in terms of body weight at 18 week of age. In the study, the hens have similar body weight at 18 week of age showed that the hens used in this study were homogeneous. The hens carried similar traits in regard to reaching $50 \%$ production age in respect to husbandry systems in this study. In a study by Sekeroglu et al (2010) which using Atak-S hybrids were used, the $50 \%$ production age was reported to be 168.75 days in deep-litter system and 160 days in free-range system. In both husbandry systems, the hens had similar egg production traits. On the contrary, this could be regarded as on important for animal welfare. The free range system provides an environment where hens can move more freely compared to the deeplitter system. Senčic' \& Butko (2006) have reported that the egg production rate of hens reared in free range system is lower than that of those reared in cage system. On the other hand, Sekeroglu et al (2010) have reported that the egg production in deep-litter, free-range and cage systems are 96.44, 118.08 and 111 respectively, whereas Pavlovski et al (1992) have reported that with Isa Brown hens in a production period of 72 weeks in the same order egg production is 291,255 and 248.

In our study, it was determined that the husbandry systems do not affect egg weight. However, Doley et al (2010), found that egg weight is higher in deep-

Table 2- Body weight at 18 week of age, $50 \%$ egg production age, hen-day egg production and average egg weight

\begin{tabular}{lcccc}
\hline \multirow{2}{*}{ Groups } & $\begin{array}{c}\text { Body weight at 18 } \\
\text { week of age }\end{array}$ & $\begin{array}{c}\text { 50\% production } \\
\text { age (day) }\end{array}$ & $\begin{array}{c}\text { Hen-day egg } \\
\text { production (\%) }\end{array}$ & $\begin{array}{c}\text { Average egg } \\
\text { weight }(g)\end{array}$ \\
\cline { 2 - 5 } & $\bar{X} \pm S_{\bar{x}}$ & $\bar{X} \pm S_{\bar{x}}$ & $\bar{X} \pm S_{\bar{x}}$ & $\bar{X} \pm S_{\bar{x}}$ \\
\hline Free-range & $1389.70 \pm 9.47$ & $161.63 \pm 1.45$ & $81.31 \pm 2.38$ & $61.91 \pm 0.55$ \\
Deep-litter & $1389.90 \pm 13.60$ & $160.50 \pm 0.50$ & $81.66 \pm 2.41$ & $61.36 \pm 0.66$ \\
\hline $\mathrm{P}$ & 0.986 & 0.692 & 0.922 & 0.522 \\
\hline
\end{tabular}

Table 3- Feed consumption, feed efficiency, viability and final body weight

\begin{tabular}{lcccc}
\hline \multirow{2}{*}{ Groups } & $\begin{array}{c}\text { Feed } \\
\text { consumption }(g)\end{array}$ & Feed efficiency & $\begin{array}{c}\text { Viability } \\
(\%)\end{array}$ & $\begin{array}{c}\text { Final body } \\
\text { weight }(g)\end{array}$ \\
\cline { 2 - 5 } & $\bar{X} \pm S_{\bar{x}}$ & $\bar{X} \pm S_{\bar{x}}$ & $\bar{X} \pm S_{\bar{x}}$ & $\bar{X} \pm S_{\bar{x}}$ \\
\hline Free-range & $131.82 \pm 1.23$ & $2.39 \pm 0.05$ & $95.39 \pm 3.76$ & $1893 \pm 46.7$ \\
Deep-litter & $131.83 \pm 2.77$ & $2.48 \pm 0.06$ & $93.24 \pm 1.35$ & $2050 \pm 42.9$ \\
\hline P & 0.995 & 0.263 & 0.694 & 0.017 \\
\hline
\end{tabular}


litter system, and Pavlovski et al (1992) pointed out that egg weights differ in cage, deep-litter and free range systems. Senčic' \& Butko (2006) reported that eggs in free range system are heavier than those in cage system whereas Torges \& Matthes (1975), Wegner (1982), Pavlovski et al (2004), Clerici et al (2006) and Samiullah et al (2014) reported that eggs produced in free range system are lighter than those produced in cage system. It is believed that different findings reported in different studies could be due to the fact that the free range systems have not reached a standard structure like the other systems.

The husbandry systems focused in the study have affected feed consumption and feed efficiency similarly. Pointing out that husbandry systems are effective on feed consumption, Sekeroglu et al (2010) stated that in Atak-S hens feed consumption in deep-litter, free-range and cage systems are 157.21, 146.7 and 134.33 g respectively, Pavlovski et al (1992) reported that feed consumption for each egg in cage, deep-litter and free range system are 172,166 and $178 \mathrm{~g}$. In the study by Senčic' \& Butko (2006) it was found that hens reared in the free range system consume more feed compared to those reared in cage system. Although it was not reported in studies, it was predicted that there could be differences in findings also in terms of feed efficiency. In this study, that no difference was found in terms of feed consumption and feed efficiency could be due to the fact that green grazing grounds provided in the $4 \mathrm{~m}^{2}$ area allocated to each hen. Moreover, the final body weights of hens reared in the deep-litter system was found to be higher than those reared in the free range system. It was predicted that, this stems from the fact that hens accommodated in the deep-litter system move less compared to the hens in the free range system. It was thought that, no difference was found in terms of feed consumption and feed efficiency between husbandry systems because the body weight of hens in the deep-litter system is higher than those in the free range system.

In a study conducted by Doley et al (2010) hens reared in the deep-litter system gain more body weight compared to those reared in the free range and semi intensive systems. This result supports the research findings of the present study. However, Pavlovski et al (1992) reported that the body weight of Isa Brown hens reared in cage, deep-litter and free range systems after 72 weeks of production are 1810, 1866 and $1912 \mathrm{~g}$ respectively. This result contradicts with the findings of the present study.

The viability values of the hens used in the study through 52 week production period were not affected by the husbandry systems. In a study comparing deep-litter, free range and cage husbandry systems, Wegner (1982) reported that mortality was lower in the cage system. In their study compared cage, deep-litter and free range systems using Isa Brown hens. Pavlovski et al (1992) reported the death rates through a production period of 72 weeks $10.8 \%$, $4.3 \%$ and $7.7 \%$, respectively. In this study, the lowest mortality was observed in the deep-litter system.

In this study, there was no difference in yield characteristics between husbandry systems. It is thought that this is caused by the fact that hens fed on the same feed.

\section{Conclusions}

When the research results are evaluated, it is seen that there is not an important difference between the two husbandry systems in terms of production traits. In the study, the difference emerging in terms of final body weight has pointed to positive results in favor of free range system. Considering animal rights and consumer preference, it could be said that free range husbandry is a more suitable option provided that the conditions specified in the study are met. However, the climate conditions of the region should be primarily taken into account in the application of free range system. It would be more suitable for free range egg production husbandry to be applied in regions with temperate climatic conditions which are neither too cold or too hot and at the same time where green grass is found in open areas throughout the year. 


\section{Acknowledgements}

We would like to express our thanks to the Ordu University.

\section{References}

Anderson K E (2009). Overview of natural and organic production: Looking back to the future. Journal of Applied Poultry Research 18: 348-354

Angelovičová M, Ševčíková V, Angelovič M \& Bučko O (2014). Comparison of two different breeding systems of laying hens in relation to egg shell quality. Animal Science Biotechnology 47(2): 166-171

Clerici F, Casiraghi E, Hidalgo A \& Rossi M (2006). Evaluation of eggshell quality characteristics in relation to the housing system of laying hens. $12^{\text {th }}$ European Poultry Conference, 10-14 September, Verona, Italy, pp. 277

Doley S, Barua N \& Kalita N (2010). Effect of rearing systems on meat and egg qualities in indigenous fowls. Indian Veterinary Journal 87(2): 168-170

Hanusová E, Hrnčár C, Hanus A \& Oravcová M (2015). Effect of breed on some parameters of egg quality in laying hens. Acta Fytotechnica et Zootechnica 18(1): 20-24

Hill J A (1986). Egg production in alternative systems-a review of recent research in the UK. Research and Development in Agriculture 3(1): 13-18

Leyendecker M, Hamann H, Hartung J, Kamphues J, Ring C, Glunder G, Ahlers C, Sander I, Neumann U $\&$ Distl O (2001). Analysis of genotype-environment interactions between layer lines and hen housing systems for performance traits, egg quality and bone breaking strength $2^{\text {nd }}$ communication: Egg quality traits. Züchtungskunde 73(4): 308-323

Malik S \& Singh N P (2010). Performance of CARI Nirbheek in agroclimatic conditions of Tripura. Indian Journal of Animal Science 80(12): 1213-1216

Nistor L I, Albu A \& Usturoi M G (2014). Knowledge of chemical indicators of eggs from hens reared in conventional and free range system. Food Science \& Technology 71(2): 119-124

Nistor L I, Albu A, Nistor A C \& Usturoi M G (2015). Aspects of eggs quality provided from free range and conventional systems. Journal of Microbiology Biotechnology and Food Science 5(2): 186-189

Pavlovski Z, Mašic' B, Josipovic' S \& Hopic' S (1992). The effect of the system of housing on the laying performance of hens in small flocks. Biotechnologija u Stočarstvu 8(1-2): 57-63

Pavlovski Z, Škrbic' Z \& Lukic' M (2004). Influence of housing type on internal and external quality of eggs in small flocks of hens. Živinarstvo 39(6-7): 9-23

Samiullah S, Roberts J R \& Chousalkar K K (2014). Effect of production system and flock age on egg quality and total bacterial load in commercial laying hens. Journal of Applied Poultry Research 23(1): 59-70

Sekeroglu A, Sarica M, Demir E, Ulutas Z, Tilki M, Saatci M \& Omed H (2010). Effects of different housing systems on some performance traits and egg qualities of laying hens. Journal of Veterinary and Animal Advances 9(12): 1739-1744

Senčic' Đ \& Butko D (2006). Productivity of layers and egg quality in free range and cage system of housing. Poljoprivreda 12(2): 48-51

Torges G \& Matthes S (1975). Investigations on the effect of type of management of laying hens (free-range, on the floor or in cages) on egg quality characters. Kleintierzucht in Forschung und Lehre, Celler Jahrbuch 23: 18

Wegner R M (1982). Investigation of production systems for laying hens with regard to ethological aspects. Landbauforsch 32(3): 162-166

Yang H M, Yang Z, Wang W, Wang Z Y, Sun H N, Ju X J \& Qi X M (2014). Effects of different housing systems on visceral organs, serum biochemical proportions, immune performance and egg quality of laying hens. European Poultry Science 78: doi:10.1399/ eps. 2014.48 